\title{
The Effects of Different Substrate Combinations on Growth and Yield of Oyster Mushroom (Pleurotus ostreatus)
}

\author{
Charles Muswati $\mathbb{D}^{1},{ }^{1}$ Kennedy Simango $\mathbb{D}^{1},{ }^{1}$ Linda Tapfumaneyi $\mathbb{D},{ }^{1}$ Moses Mutetwa $\left(\mathbb{D},{ }^{2}\right.$ \\ and Wonder Ngezimana $\mathbb{D}^{1}$ \\ ${ }^{1}$ Marondera University of Agricultural Sciences and Technology, Department of Horticulture, P. Bag 35, Marondera, Zimbabwe
${ }^{2}$ Midlands State University, Faculty of Natural Resources Management and Agriculture,
Department of Agronomy and Horticulture, P. Bag 9055, Gweru, Zimbabwe
}

Correspondence should be addressed to Moses Mutetwa; mosleymtetwa@gmail.com

Received 4 March 2021; Revised 22 April 2021; Accepted 13 May 2021; Published 22 May 2021

Academic Editor: Maria Serrano

Copyright ( $) 2021$ Charles Muswati et al. This is an open access article distributed under the Creative Commons Attribution License, which permits unrestricted use, distribution, and reproduction in any medium, provided the original work is properly cited.

\begin{abstract}
This research was aimed at evaluating the effect of mixing substrates on the growth and yield of Oyster mushrooms (Pleurotus ostreatus). Seven substrates, namely, Trt1 (cotton waste), Trt2 (wheat straw), Trt3 (crushed baobab fruit shells, 100\%), Trt4 (cotton husk + wheat straw + crushed baobab fruit shells, 1:1:1), Trt5 (baobab fruit shells + cotton husks, 1:1), Trt6 (baobab fruit shells + wheat straw, $1: 1$ ), and Trt7 (cotton waste + wheat straw, $1: 1$ ) were used. Each treatment was replicated 5 times and laid out in a CRD. The duration of developmental stages, yield, and biological efficiency was recorded. Cotton waste demonstrated a significantly $(p<0.05)$ higher mycelial colonization rate taking an average of 18.20 days to complete full spawn run, 23.20 days from spawning to pinhead formation, 2.80 days for pins to mature, and an average of 26.00 days to first harvest. There was a significant $(p<0.05)$ difference in the total number of pins with cotton waste being the highest with an average of 29.80 pins, although it was not significantly different from Trt4. The highest $(5.40 \mathrm{~cm})$ stipe girth was recorded from Trt4 while the highest $(5.22 \mathrm{~cm})$ cap diameter was recorded in Trt1. There was a significant $(p<0.05)$ difference in yield and biological efficiency. Trt1 had the highest $(1.292 \mathrm{~kg})$ average yield; however, it was not significantly $(p>0.05)$ different from that of Trt4 (1.289 kg). From the research, it was observed that mixing substrate can help to increase yield and, as a result, a higher benefit-cost ratio. Therefore, further studies should be done to evaluate the effects of mixing other substrates besides the ones used in this current research.
\end{abstract}

\section{Introduction}

The world over food production is being threatened by the adversative effects of climate change. For that reason, SubSaharan Africa needs to intensify agricultural production to feed its growing population adequately for food security and food safety in a stainable manner [1]. On that note, about $70 \%$ of Zimbabwe's population is dependent on agricultural outputs [2] and the region is facing some serious challenges of food security due to droughts and the repeated use of agricultural land over several years has created a remarkable reduction in soil fertility $[3,4]$ resulting in poor harvests. Therefore, Sub-Saharan African nations need to combat the food security situation with a scientific, economic, and technologically based approach [5]. One way to do it is through mushroom production to augment in food security and nutrition of the nation. Oyster mushrooms (Pleurotus ostreatus) with their ability to grow within a short space of time, using agricultural wastes, less space, and less water as compared to other field crops, have been identified as an excellent food source to alleviate malnutrition in Zimbabwe [6]. Oyster mushroom is commercially cultivated worldwide for its incredible taste and medicinal and nutritional properties [7]. Mushrooms are used as relish in many countries like China, Ghana, and many others. They can be used to make very expensive sauces and soups in Asian countries such as China and Korea. Mushrooms are considered a very rich source of nonstarchy carbohydrates, 
dietary fiber and proteins, most amino acids, minerals, and vitamins $[8,9]$. They are a rich source of protein and are used as a substitute for meat in vegetarian diets. It has been reported by Stanely and Odu [10] that oyster mushroom constitutes of $25-30 \%$ protein, $2.50 \%$ fat, $17-44 \%$ sugar content, 7-38\% mycocellulose, and approximately 8-12\% mineral (potassium, phosphorus, calcium, and sodium). Furthermore, mushrooms contain a great quantity of dietary fiber and given their chemical structure, they show immunostimulatory and anticancer activity [11-13]. Other biological properties of the mushrooms are being antidiabetic, antioxidant, and antitumor [14-17].

Due to benefits derived from mushroom production, many indigenous and commercial cultivation methods have been developed and put in place to domesticate mushrooms [18]. Cultivation of oyster mushroom on tree stumps and wood logs was initiated on an experimental basis in Germany by a scientist called Flack in the year 1917. The growing technology was later perfected in the USA by Block, Tsao, and Hau [19]. Cultivation of mushrooms has become a very profitable commercial agribusiness in most developing and developed countries such as the USA, Great Britain, China, Asia, Japan, Europe South Africa, and Ghana with China as the biggest producer producing about 3,918,300 tons each year [18]. China produces more than $85 \%$ of all oyster mushrooms worldwide; however, $95 \%$ of the total China production is for domestic consumption [20, 21]. Despite the potential benefits from mushroom production and consumption, Africa desperately lags in mushroom production and trade [21]. About two decades ago, the world production of cultivated edible mushrooms was estimated to be about 7 million tonnes [22] and the combined total market value for both edible and medicinal mushrooms for the same period was estimated to be over US\$30 billion [23]. Notwithstanding processing so many biological wastes, Africa is found to contribute less than $1 \%$ to this estimated value. In some of the southern African countries, mushroom production technology is almost nonexistent while, in other countries, there is little production.

Pleurotus spp. is one of the most widely studied white-rot fungi for its excellent ligninolytic properties [24-26]. Pleurotus species need a short growth time, as compared to other mushrooms. Its fruiting body is hardly ever attacked by pests and diseases and it can be grown simply and cheaply, sporelessness, with high yield, wider substrate utilization, wide chemical, and temperature tolerance, as well as environmental bioremediation [27]. Mushroom multiplication and survival are related to several factors, which may act exclusively or have interactive effects among them. Chemical composition, the ratio of carbon (C) to nitrogen $(\mathrm{N})$, sources of $\mathrm{N}$, surfactant, minerals, $\mathrm{pH}$, water activity, moisture, particle size, and amount of inoculum, antimicrobial agents, and the existence of interactions between microorganisms are considered as chemical, physical, and biological aspects that are linked to mushroom production [28]. The key environmental variables encompass luminosity, humidity, temperature, and air composition of the surrounding substrate, such as the concentration of carbon dioxide and oxygen, which affect the yield and
TABLE 1: Base substrates and their composition as used in this experiment as substrate material.

\begin{tabular}{lc}
\hline Treatment & Composition by weight \\
\hline Trt1 & $100 \% \mathrm{CW}$ \\
Trt2 & $100 \% \mathrm{WS}$ \\
Trt3 & $100 \% \mathrm{BFS}$ \\
Trt4 & $53.3 \% \mathrm{CW}+33.3 \% \mathrm{WS}+33.3 \% \mathrm{BFS}=100 \%$ \\
Trt5 & $50 \% \mathrm{BFS}+50 \% \mathrm{CW}$ \\
Trt6 & $50 \% \mathrm{BFS}+50 \% \mathrm{WS}$ \\
Trt7 & $50 \% \mathrm{CW}+50 \% \mathrm{WS}$ \\
\hline
\end{tabular}

CW: cotton waste; WS: wheat straw; BFS: baobab fruit shells.

quality of oyster mushrooms [29]. Many industrial and agricultural by-products are vital in mushroom production including, wood chips, coffee pulp, and teff straw, and cotton waste has vast lignin, cellulose, and hemicellulose contents [30]. Consequently, there are a few studies done on the utilization efficiency of agricultural by-products in mushroom farming. Hereafter, this current investigation was carried out to appraise the growth, the economic practicability of small-scale production, and yield (bioconversion efficiency) of oyster mushrooms using locally available agroindustrial by-products.

Currently, the mushroom production sector in Zimbabwe is anchored by small-scale farmers, most of which are women. In research by Mutema et al. [31], it has been revealed that lack of financial support, marketing problems, and lack of space for production, training, quality of spawns, temperature control, mushroom diseases, people's negative attitude, water shortages, and substrates are the major contributors to the decline of mushroom production in Zimbabwe. The ability of oyster mushrooms to grow from a wide variety of agricultural and forestry wastes like corn cobs, wheat straw, rice hulls, sawdust, and many other wastes has led to its use as one of the environmentally friendly solutions of transforming wastes into biomass of high market value $[6,32,33]$ and with the potential for reuse of the mushroom substrate in either mushroom production all over again or in farming land as organic fertilizers to maximize yields while minimizing chemical fertilization [34]. Therefore, this research was aimed at determining the efficiency of combining crushed baobab fruit shells, wheat straw, and cotton husks for the production of oyster mushroom to maximize yields and provision of a cheap source of protein to the growing nation of Zimbabwe.

\section{Materials and Methods}

The study on the effects of different substrate combinations on the growth and yield of grey oyster mushroom (Pleurotus ostreatus) was conducted at Marondera University of Agricultural Sciences and Technology, Dozmery Campus which is located $40 \mathrm{~km}$ from Marondera town along Ruzavi road. The Grey HK35 strain was obtained on the commercial market and subcultured in the university laboratory. The trial was laid out in a completely randomized design with 5 replications for each substrate treatment. Three base substrates of cotton waste (CW), wheat straw (WS), and baobab 
fruit shells (BFS), in addition to 4 mixtures made from the three base substrates, were evaluated (Table 1). The wheat straw was collected from the Department of Research and Specialist Services farm in Harare. The wheat straw was then chopped into $2-3 \mathrm{~cm}$ pieces. The baobab fruit shells were obtained from Mbare Musika and they were crushed into 2$3 \mathrm{~cm}$ pieces using a crusher. The cotton waste was collected from Glenview complex, Harare.

2.1. Substrate Preparation. A $7.5 \mathrm{~kg}$ dry weight of each treatment substrate was soaked for 8 hours in 40 liters of water containing 100 grams of hydrated lime $\left(\mathrm{Ca}(\mathrm{OH})_{2}\right)$ for cold pasteurization. Water and $\mathrm{Ca}(\mathrm{OH})_{2}$ were mixed for 2 minutes to ensure a perfect homogenization before soaking the substrate as explained by Contreras et al. [35]. The substrates were then drained to remove excess water and packed into transparent plastic standard loaf packs for spawning according to ratios shown in Table 1 . The grain spawn was produced using sorghum seeds, according to the following steps: the selection of mushroom, production of the subculture, production of mother spawn, and production of grain spawn as outlined in the method presented by Zied et al. [8]. The triple spawning procedure was used as described by Tavarwisa et al. [6]. Eighty grams of sorghum grain Grey HK35 strain spawn was used per each transparent polyethylene bag with approximately $2 \mathrm{~kg}$ of substrate. The fruiting bags were then hanged in a dark fruiting house where moisture was constantly supplied until the spawn run was complete and the room temperature maintained within the temperature range of $18-21^{\circ} \mathrm{C}$. After the spawn run was complete, the mushroom bags were punched to create holes through which the mushroom grows out of the polyethylene bags, and then the fruiting bags were taken to the fruiting house. Six holes were punched along the length of the plastic on all four sides of the plastic giving a total of 24 holes. In the fruiting house, the bags were hung on horizontal poles, water was sprayed onto the bags to keep them moist, the floors were also wetted to help increase the humidity to not less than $85.0 \%$, and temperature was maintained in the range of $14-18^{\circ} \mathrm{C}$. Harvesting was done by cutting the bigger mushrooms at the base to allow the base itself and smaller mushrooms to continue growing.

\subsection{Determination of the Substrate Water Holding Capacity.} From each treatment, $200 \mathrm{~g}$ of the substrate was extracted and placed inside a beaker to which $400 \mathrm{ml}$ of water was
TABLE 2: The effect of different substrate treatments on mushroom growth parameters investigated.

\begin{tabular}{lccccccc}
\hline \multirow{2}{*}{ Treatment } & \multicolumn{7}{c}{ Time (days) } \\
& S-CSR & S-PF & PF-PM & DFH & TNP & SG & QS \\
\hline T1 cw & $18.2^{\mathrm{a}}$ & $23.2^{\mathrm{a}}$ & $2.8^{\mathrm{a}}$ & $26.0^{\mathrm{a}}$ & $29.8^{\mathrm{a}}$ & $4.7^{\mathrm{ab}}$ & $9.8^{\mathrm{a}}$ \\
T2 ws & $24.2^{\mathrm{b}}$ & $30.8^{\mathrm{c}}$ & $3.0^{\mathrm{ab}}$ & $33.8^{\mathrm{bcd}}$ & $23.8^{\mathrm{bc}}$ & $4.1^{\mathrm{ab}}$ & $9.2^{\mathrm{ab}}$ \\
T3 bfs & $21.0^{\mathrm{b}}$ & $30.0^{\mathrm{bc}}$ & $4.2^{\mathrm{cd}}$ & $34.2^{\mathrm{cd}}$ & $25.8^{\mathrm{abc}}$ & $4.5^{\mathrm{ab}}$ & $9.6^{\mathrm{a}}$ \\
T4 & $20.0^{\mathrm{ab}}$ & $24.0^{\mathrm{a}}$ & $3.4^{\mathrm{abc}}$ & $27.4^{\mathrm{a}}$ & $29.2^{\mathrm{ab}}$ & $5.4^{\mathrm{a}}$ & $9.0^{\mathrm{ab}}$ \\
T5 bfs cw & $20.6^{\mathrm{ab}}$ & $27.2^{\mathrm{b}}$ & $4.0^{\mathrm{bcd}}$ & $31.2^{\mathrm{cd}}$ & $23.4^{\mathrm{c}}$ & $4.1^{\mathrm{ab}}$ & $8.6^{\mathrm{bc}}$ \\
T6 bfs ws & $25.0^{\mathrm{c}}$ & $31.0^{\mathrm{c}}$ & $4.6^{\mathrm{d}}$ & $35.6^{\mathrm{d}}$ & $20.6^{\mathrm{c}}$ & $5.0^{\mathrm{a}}$ & $8.4^{\mathrm{bc}}$ \\
T7 cw ws & $21.0^{\mathrm{b}}$ & $27.6^{\mathrm{b}}$ & $4.2^{\mathrm{cd}}$ & $31.8^{\mathrm{bc}}$ & $24.8^{\mathrm{c}}$ & $3.5^{\mathrm{b}}$ & $7.8^{\mathrm{c}}$ \\
Mean & 21.43 & 27.69 & 3.74 & 31.43 & 25.34 & 4.46 & 8.97 \\
p value & $<0.001$ & $<0.001$ & 0.006 & $<0.001$ & $<0.001$ & 0.004 & 0.002 \\
CV\% & 9.9 & 8.1 & 20.7 & 7.0 & 10.7 & 15.7 & 8.3 \\
\hline
\end{tabular}

Within the columns, means followed by the same superscript letter are not significantly different, $\mathrm{LSD}_{0.05}$. S-CSR: spawning to complete spawn run; SPF: spawning to pinhead formation; QS: quality score; DFH: days to first harvests; TNP: total number of pins; SG: stipe girth; PF-PM pinhead formation to pin maturation.

added. The mixtures were left overnight for the substrate to absorb as much water as possible. The setup was replicated five times for each treatment. Excess water was filtered through a filter paper into a measuring cylinder. The volume of the filtrate was recorded and the water that was retained by the substrate was calculated by subtracting the volume of water collected in the measuring cylinder from the total volume of water applied to each treatment and was expressed as $\mathrm{g}$ of water per $200 \mathrm{~g}$ substrate.

2.3. Data Collection. The number of days from spawning to complete spawn run was recorded, and after two weeks of spawning, the spawned bags were checked daily. Days took from complete spawn run to pinhead formation, time taken from pin formation to pin maturation, and the number of days from spawning to the first harvest were recorded in days. The total number of pins (TNP) formed during the first and second flashes were recorded based on the total number of pins formed. Stipe girth (SG) and cap diameter were measured. Quality (QS) was measured by recording the number of blemishes, deformities, size, and color. The yield was measured in terms of the fresh weight $(\mathrm{kg})$ of the oyster mushrooms. The effectiveness of a mushroom strain and substrate was measured. Biological efficiency was calculated using the following formula:

$$
\text { biological efficiency, BE }(\%)=\frac{\text { fresh weight of harvested mushrooms }}{\text { weight of dry substrate }} \times 100 \text {. }
$$

2.4. Data Analysis. The economic analysis of the different substrate treatments was determined by calculating the benefit: cost ratio of each treatment. Statistical evaluations of the above- mentioned parameters were done by one-way ANOVA using Genstat statistical software package and the mean comparisons were done using Fisher's protected LSD at $p<0.05$. 


\section{Results}

3.1. Days from Spawning to Full-Spawn (S-CSR). There was a significant difference $(p<0.05)$ in the number of days taken from spawning to complete spawn run (Table 2). Cotton waste (Trt1) took the least number of days (18.20) to complete the spawn run followed by a mixture of cotton and wheat straw (Trt7) and baobab fruit shells (Trt3) with 21 and 25 days, respectively. A combination of baobab fruit shells and wheat straw (Trt6) took the longest number of days (25.00) to complete the spawn run as compared to the other substrates. The number of days to complete spawn run ranged from 18 to 25 days and the mean number of days was 21.43.

3.2. Days from Spawning to First Pinhead Formation (S-PF). Data patterning time taken from spawning to first pinhead formation is shown in Table 2. The data reveal that there was a significant difference $(p<0.05)$ in the time taken from spawning to first pinhead formation among the different substrates. Treatment Trt1 (23.2) followed by treatment Trt5 (27.2) recorded the least number of days to pinhead formation. Treatment Trt6 registered the highest number of days from spawning to pinhead formation. The time taken from spawning to pinhead formation ranged between 23 and 31 days. The mean days from spawning to pinhead formation were 27.7.

3.3. Time Taken to Pin Maturity (PF-PM). The time taken from pinhead formation to pin maturation varied significantly $(p<0.05)$ among the different substrates investigated (Table 2). Pins from Trt1 took the shortest (2.8) time to reach maturity followed by pins from Trt5 (4.0). Pins in Trt6 took the longest (4.6) time to reach maturity from the time of formation. The time taken from pin development to pin maturation ranged from 2.8 to 4.6 days. The mean number of days taken from pin formation to maturity was 3.7.

3.4. The Number of Days to the First Harvest. Table 2 shows data regarding the number of days taken to reach the first harvest from each substrate investigated was statistically significant $(p<0.05)$. The least $(26.0)$ number of days was recorded from Trt1. Treatments Trt7 (31.8), Trt2 (33.8), Trt3 (34.2), and Trt6 (35.6) recorded days that were higher than the mean (31.4) of all the substrate treatments under investigation. The number of days to reach the first harvest ranged from 26.0 to 35.6 .

3.5. The Total Number of Pins (TNP). Results in Table 2 reveal that the total number of pins of oyster mushrooms from the different substrate treatments differed significantly $(p<0.05)$. Treatment Trt1 registered the highest (29.8) number of pins. Treatments Trt6 (20.6), Trt5 (23.4), Trt2 (23.8), and Trt7 (24.8) recorded a number of pins that were lower than the mean (25.3) for all the substrate treatments under investigation. The number of pins recorded ranged from 20.6 to 29.8 .
3.6. Stipe Girth (SG). Results shown in Table 2 regarding stipe girth revealed that the parameter did not strongly differ statistically $(p<0.05)$ among the substrate treatments under study. Only treatments Trt4 and Trt6 differed statistically from treatment Trt7 with regard to stipe girth. The largest (5.4) stipe girth was recorded from treatment Trt4. The stipe girth ranged from 3.4 to $5.4 \mathrm{~cm}$ and the mean circumference for all the treatments investigated was $4.5 \mathrm{~cm}$.

3.7. Quality (QS). Results of the overall quality of the mushroom reveal that the substrate treatments registered differing $(p<0.05)$ scores (Table 2$)$. It is interesting to note that all the base substrates registered scores higher than the mean (9.0) of all the substrate treatments under investigation. The results also reveal that the quality of the mushrooms from the base substrates did not differ $(p<0.05)$ from one another.

3.8. Cap Diameter $(\mathrm{cm})$. Cap diameter was significant $(p<0.05)$ among the substrate treatments under investigation (Figure 1). The largest $(5.5 \mathrm{~cm})$ cap diameter was recorded from treatment Trt1 followed by treatment Trt5 $(4.8 \mathrm{~cm})$. Treatments Trt2 $(4.1 \mathrm{~cm})$, Trt7 $(4.2 \mathrm{~cm})$, and Trt3 $(4.3 \mathrm{~cm})$ registered cap diameters that were below the mean $(4.7 \mathrm{~cm})$ of all the substrate treatments being investigated.

Bars with different letters represent significant differences at $p<0.05$.

3.9. Yield $(\mathrm{kg})$. The yield as influenced by the different substrate treatments applied in this study differed $(p<0.05)$ statistically (Figure 2 ). The treatment with the highest yield from the $2 \mathrm{~kg}$ substrate material used was Trt1 $(1.29 \mathrm{~kg})$ followed by treatment Trt7 $(0.99 \mathrm{~kg})$. It is worth noting that only treatments Trt1, Trt4, and Trt7 gave a yield that was higher than the mean $(0.96 \mathrm{~kg})$ of all the substrate treatments under investigation.

3.10. Biological Efficiency, BE (\%). Data pertaining to biological efficiency (BE) (Figure 3) shows that treatment Trt1 was significantly $(p<0.05)$ highest $(86.15 \%)$ for all the substrate treatments investigated followed by treatment Trt7 $(66.3 \%)$. It is worth noting that the majority of the treatments, namely, treatments Trt6, Trt5, Trt3, and Trt2 registered percentages $(42.5 \%, 48.6 \%, 55.0 \%$, and $61.4 \%$, respectively) below the mean $(63.7 \%)$ of all the substrate treatments investigated.

3.11. Amount of Retained Water (g). Data regarding the water holding capacity of the substrates used in the study reveal that there were significant $(p<0.05)$ differences (Figure 4). Statistically, the treatment with the highest water retained was Trt1 (126.2 g/200 g substrate) and the least ( $88.8 \mathrm{~g} / 200 \mathrm{~g}$ substrate) was registered from treatment Trt2 which, however, did not differ $(p>0.05)$ from treatment Trt6 with $92.4 \mathrm{~g} / 200 \mathrm{~g}$ substrate. The water retained registered from substrate treatments Trt7, Trt3, and Trt5 did not 


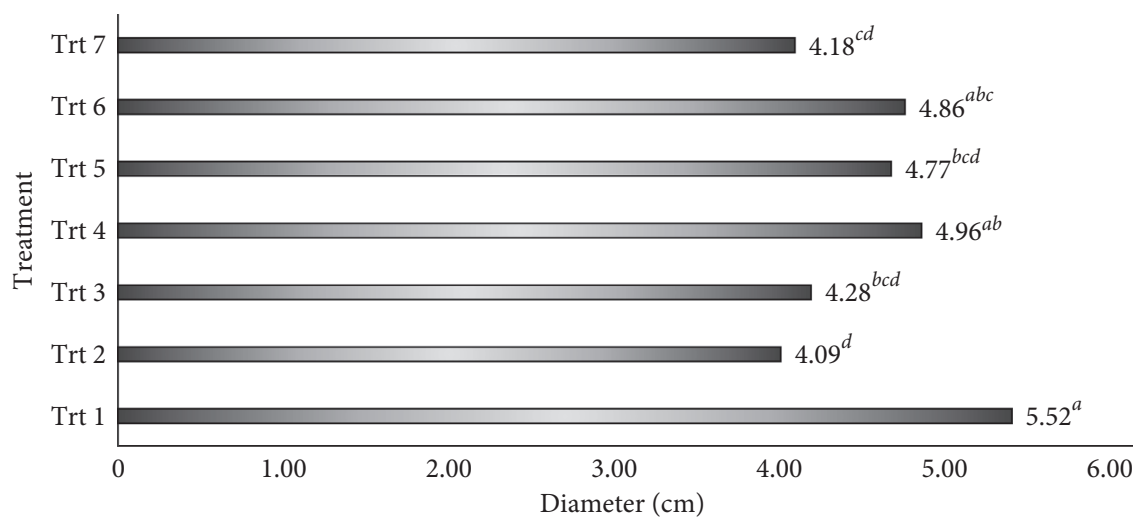

FIGURE 1: Graph showing the average cap diameter for mushrooms grown using different substrate combinations.

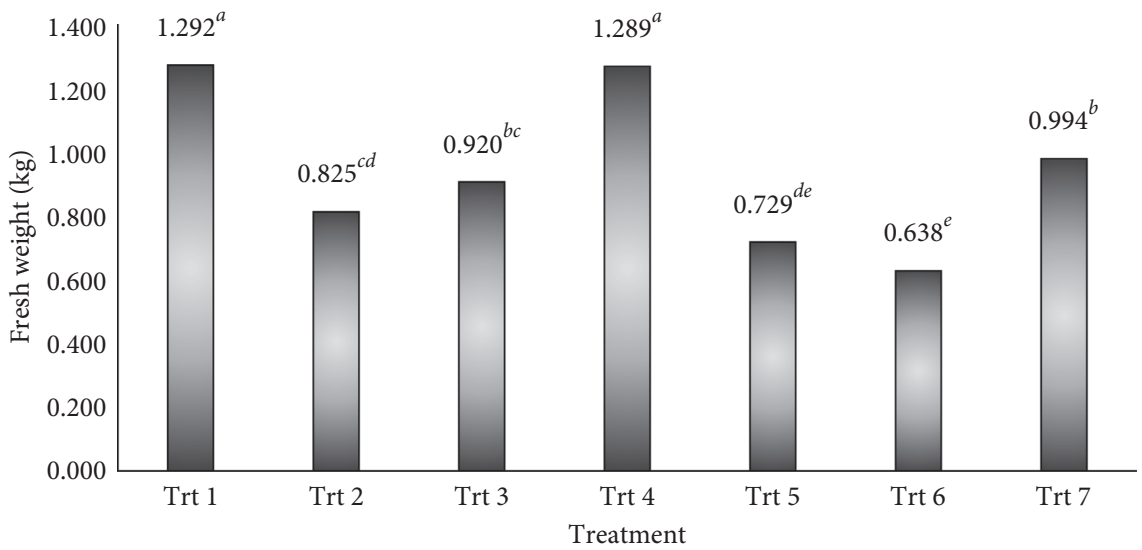

FIGURE 2: Graph showing yield of mushrooms grown using different substrate combinations.

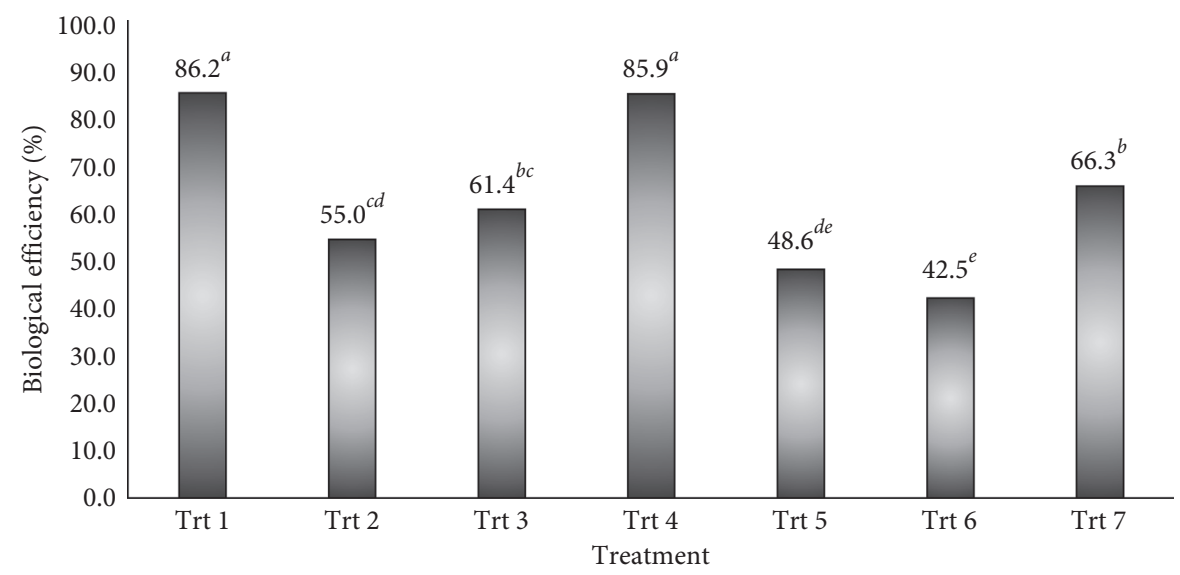

FIGURE 3: Graph showing the average biological efficiency of different substrate combinations used in the production of mushrooms.

differ from one another registering $106.4 \mathrm{~g}, 107.6 \mathrm{~g}$, and $108.8 \mathrm{~g}$ per $200 \mathrm{~g}$ substrate, respectively. The mean amount of water retained for all the substrate treatments was $107.1 \mathrm{~g}$.

3.12. Economic Analysis. The economic analysis was determined in terms of the benefit-cost $(B: C)$ ratio of the substrate treatments (Table 3 ). It is defined as the ratio of gross income from the selling of mushrooms to the total cost incurred during cultivation. When the $B: C$ is greater than 1 , the project is accepted and vice versa. The higher value of $B$ : $C$ indicates a higher level of viability of the project in an economical aspect. The highest (2.11) economic benefit was obtained from the use of substrate treatment Trt1 (cotton waste) followed by the use of substrate treatment Trt4 (cotton husk + wheat straw + crushed baobab fruit shells) with a B : C value of 1.93. The lowest (1.16) ratio was obtained from Trt6 (baobab fruit shells + wheat straw). 


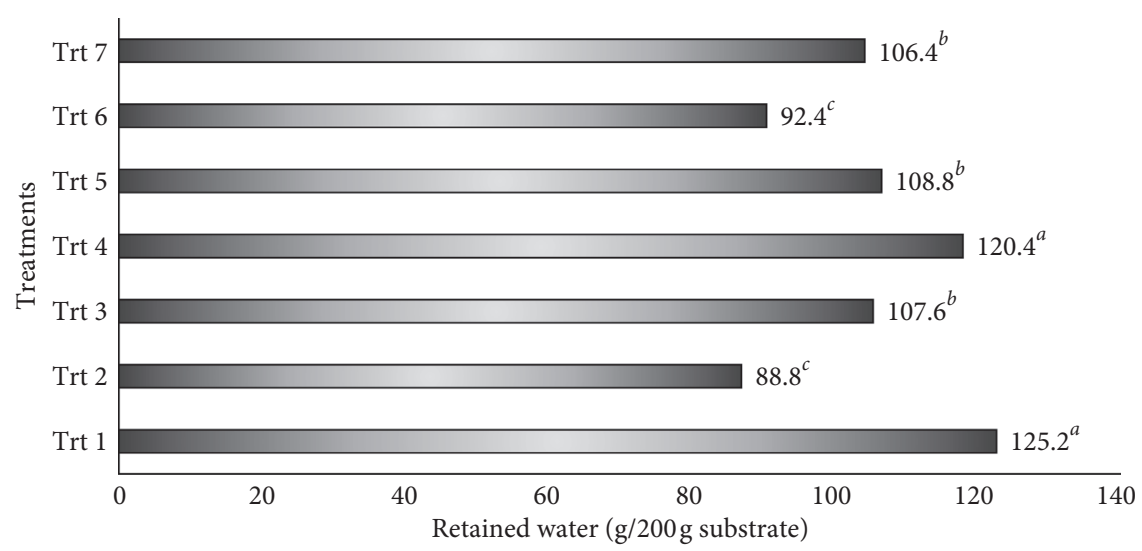

FIgURE 4: Graph showing the water holding capacity of the substrates used in the experiment.

TABLe 3: The benefit-cost ratios of the substrates used in the experiment.

\begin{tabular}{lccccc}
\hline Substrate & Cost of spawning 20 kg substrate & Yield/kg of substrate & Income/20 kg of substrate & Gross margin & Benefit-cost ratio \\
\hline Trt1 & $\$ 22.00$ & 1.2922 & $\$ 46.52$ & $\$ 24.52$ & 2.11 \\
Trt2 & $\$ 20.50$ & 0.8248 & $\$ 29.69$ & $\$ 9.19$ & 1.45 \\
Trt3 & $\$ 19.00$ & 0.9204 & $\$ 33.13$ & $\$ 14.13$ & 1.74 \\
Trt4 & $\$ 24.00$ & 1.2885 & $\$ 46.39$ & $\$ 19.89$ & 1.93 \\
Trt5 & $\$ 21.50$ & 0.7292 & $\$ 26.25$ & $\$ 2.75$ & 1.22 \\
Trt6 & $\$ 19.75$ & 0.6377 & $\$ 35.79$ & $\$ 1.21$ & 1.16 \\
Trt7 & $\$ 24.25$ & 0.9943 & & $\$ 11.54$ \\
\hline
\end{tabular}

\section{Discussion}

Mushrooms are becoming a significant component of our diets globally, for the reason of their medicinal properties and high nutritional value. In this study, seven different substrates made from 3 base substrates cotton waste, wheat straw, and crushed baobab fruit shells were compared for their performance in oyster mushroom (Pleurotus ostreatus) cultivation for times of spawn development and harvesting as well as yield and quality. The yield of cultivated mushrooms and morphological features of their fruiting bodies differed $(p<0.05)$ significantly as a result of the different physiochemical compositions of the growing substrate.

The choice of the substrate in mushroom production is of importance since it has a significant influence on the productivity of oyster mushrooms for better growth, development, and yield. Substrates of lignocellulosic materials in origin generally contain lower protein content and, as such, the production is inferior. In this study, treatments with wheat straw (Trt2) and baobab fruit shells (Trt3) obtained lower growth and yield of mushroom as compared to treatment Trt1 (cotton waste). Even when combinations of these substrates were done with cotton waste (Trt4, Trt5, and Trt7), their performance either did not significantly $(p>0.05)$ improve or was better than $\operatorname{Trt} 1$. However, when wheat straw alone (Trt2) was supplemented with cotton waste (Trt7), its performance improved significantly $(p<0.05)$ for some characters recorded such as S-CSR and S-PF. The above study results reveal that when substrates are known to have a high $C: N$ augmented by $N$-rich material, the productivity was not altered for most of the parameters. Consequently, while it is an important strategy for promoting the utilization of locally available agroindustrial by-products in mushroom farming, augmentation of the raw substrate can produce negative effects. This could be attributed to the change in the substrate composition such as $\mathrm{pH}$, temperature, moisture, aeration, and amount and activity of microbes, which affect mushroom productivity.

One of the principal factors in the cultivation of mushrooms is the growth of mycelia in the substrate. In this study, results from Trt1 showed the highest mycelial growth rate since it took the shortest time for a complete spawn run as compared to the other substrate treatments investigated. This high mycelial running rate could be attributed to the fact that cotton waste has a higher $C: N$ which favored high mycelial growth. These results closely correspond to the findings by Bhattacharjya et al. [36] who reported closely related mycelial growth rate on some of the treatment although their study dealt with sawdust as substrate. However, it is important to consider that substrates with lower final $N$ concentration may result in mushrooms poorer in protein [37]. Mushroom pinning requires conditions that are different from those required for mycelial growth [38]. Although it took longer for wheat straw (Trt2) to complete the colonization of the media, the duration from pinhead formation to maturity was significantly shorter in comparison with other substrate treatments. The total growing time of the mushroom was the longest from substrate treatment Trt6, but the total number of pins formed was significantly $(p<0.05)$ the least for all the substrate treatment investigated. $C: N$ ratio had more effects on the mycelium growth, the formation, and development of the fruiting body. This may be attributed to the decrease in carbon and nitrogen since the formation of primordia or pinheads is directly 
related to the availability of $C: N$ from lignocellulose substrate $[39,40]$. Substrate treatments with wheat straw (Trt2, Trt5, and Trt6) recorded a longer duration for mycelial growth rate but the least for the total number of pins. This was probably due to high $N$ content which is known to inhibit mushroom growth if it is in an excessive amount within the substrate [41]. These research findings show that there was a negative correlation between the $C: N$ ratio of substrates used and duration from spawning to complete spawn run. Results are also similar to findings by Alborés et al. [42] who revealed a positive correlation between mycelium running rate and the $C: N$ ratio of the substrate. The significant $(p<0.05)$ differences in stipe girth, cap diameter, and the number of primordial, as well as their quality characters between substrate treatments, suggest that substrate type is one of the major factors affecting the growth, development, fruiting, and quality of oyster mushroom. Several other authors, Besufekad et al. [30], Chukwurah et al. [43], Tsegaye and Tefera, [44], Onyeka et al. [45], and Dubey et al. [46], also observed these significant differences among different substrates. The size of the mushroom is dependent on substrates that were poor in cellulose, hemicelluloses, and lignin which constitute physical barriers and are difficult to be broken down without the presence of lignin-degrading enzymes [47]. The differences recorded regarding quality characters may be due to the differences in the rate of growth and development of the pins where quick growth might have reduced the exposure of the mushroom caps to insects and other diseases. Several studies have also demonstrated the need to supplement nitrogen-poor substrates with wheat or soybean bran or to combine different straws or grasses for Pleurotus cultivation [48-53].

The main purpose of mushroom cultivation is yield. The current study reveals that the yield was influenced differently by the different substrate treatments used in cultivation. The differences in the yield had also an impact on the biological efficiency of the substrate treatments. In general, substrates that gave higher yield also give a higher $\mathrm{BE}$ value. Results from substrate treatments Trt1 and Trt4 registered the highest yield, as well as the highest $\mathrm{BE}$ whereas results from Trt5 and Trt6 registered the lowest yield, as well as the lowest BE values. The works of Girmay et al. [54] also reported a $74.2 \%$ biological efficiency in cotton waste and also Islam and Riaz [55] recorded a 92.9\% biological efficiency for the same substrate. Wang et al. [56] showed that there was a positive correlation between $\mathrm{BE}$ and degradation of cellulose and hemicellulose whereas a negative relationship between $\mathrm{BE}$ and lignin degradation was observed. Substrate treatments Trt1 and Trt4 suggest that they are more suitable for mushroom production in terms of yield and BE compared to other substrates.

The differences in terms of yield and $\mathrm{BE}$ of oyster mushrooms grown on different substrate types are attributed to the differences in the physical and chemical composition of substrate formulas such as cellulose/lignin ratio and mineral contents, $\mathrm{pH}$, and $\mathrm{EC}$ of the substrate, especially $C$ : $N$ ratio [57]. The low $N$ in substrate treatment Trt2 probably was one factor affecting the overall yield and $\mathrm{BE}$ compared to other raw substrates. When the raw substrates $\operatorname{Tr} t 2$ and $\operatorname{Tr} 3$ were gradually replaced by the cotton waste in the substrate formulas, Trt7 and Trt5, respectively, the $N$ was enhanced; thus, $C: N$ ratio decreased and, as a result, the substrate supported better mushroom yield than the higher $C: N$ ratio substrates.

The yield obtained suggests that the substrate which is used more by the enzymatic activity of the fungal gave more yield. The higher the mycelium running rate in substrate treatments Trt1 and Trt4, the higher the substrate water holding capacity, and probably the suitable $C: N$ ratio might be responsible which in turn gave higher yield. However, this is not true for substrate Trt5 which had a higher mycelium running rate and higher water holding capacity but gave a significantly lower yield. The biological efficiency and yield varied significantly due to the effect of different substrate compositions on the substrate treatments. The composition differences in the $C: N$ between Trt1, Trt4, and Trt5 could then be attributed to the differences in yield and BE. Studies from other authors $[58,59]$ registered a similar trend and this result could be ascribed to the easily metabolizable organic sources of $N$ in the substrates for higher yield and higher BE. Furthermore, the result could be attributed to the mushroom metabolizing the easily degradable carbon sources of substrate materials in an energetically efficient way than the breakdown of complex carbohydrate as lignin, cellulose, and hemicellulose in the other substrate composition. However, according to Gume et al. [60], all the substrate treatments used in this research can be recommended for oyster mushroom cultivation since they gave over a BE of over $40.0 \%$.

In terms of the economic analysis, the highest $B: C$ ratio was observed from Trt1 and Trt4. This was attributed to the high yields obtained from the use of these substrates. The cost of the substrate was higher for Trt1 than Trt6 but the B: $C$ was higher for Trt1 as a result of the significantly higher yield which meant a higher gross income. Therefore, the yield obtained from the different substrates contributes significantly to the determination of the economic benefit of the substrate.

\section{Conclusion and Recommendations}

The outcomes registered in this current investigation stipulate that the performance and productivity of the Pleurotus ostreatus mushroom were highly influenced by the substrate from which it was grown. The substrates media were found to influence the duration of mycelium running, pinhead formation, the number of fruit bodies produced, the cropping time, the primordial diameter, and the biological efficiency of oyster mushroom. The results from the research show that mixing substrate can help to increase mushroom yield since a combination of cotton husk, wheat straw, and crushed baobab fruit shells (Trt4) performed better than the commonly used raw substrate such as wheat straw (Trt2) or use of the less common raw baobab fruit shells (Trt3). This may be important to farmers who may be in short supply of the substrates; therefore, mixing substrates that are in short supply can enable farmers to attain their target yields. 
Mixing of substrates may help in the optimization of the compositional characters such as water holding capacity, increased substrate structure, porosity that improves water penetration and gaseous exchange, and an optimum $C: N$ ratio that improves the efficiency of the substrates. Accordingly, it is imperative to determine the $N$ content of each raw agroindustrial by-product used in the mix of the substrate for mushroom production and then resolve on suitable combinations proportions. These results can help baobab producers to manage baobab waste sustainably. Based on the results in this study, it is recommended that mushroom producers use the substrate options that gave the highest $B: C$ ratio, which is cotton waste and/or a combination of cotton husk, wheat straw, and crushed baobab fruit shells. Recommendation on further studies can be done on the effects of mixing other substrates other than the ones used in this experiment and varying the proportions as well.

\section{Data Availability}

The raw data used to support the findings of this study are available from the corresponding author upon request.

\section{Conflicts of Interest}

The authors declare that there are no conflicts of interest regarding the publication of this article.

\section{References}

[1] M. Mutetwa, K. Nyaera, T. Masaka, and T. A. Mtaita, "Effect of bio priming seeds with microbial based bio fertilizssers on growth of maize seedlings," International Journal of Research and Review, vol. 6, no. 10, pp. 281-288, 2019.

[2] J. Frischen, I. Meza, D. Rupp, K. Wietler, and M. Hagenlocher, "Drough risk to agricultural systems in Zimbabwe: a spartial analysis of hazard, exposure, and vulnerability," Sustainability, vol. 2, 2020.

[3] T. A. Mtaita, K. Nyaera, M. Mutetwa, and T. Masaka, "Effect of bio fertilizer with varying levels of mineral fertilizer on maize (Zea mays. L) growth," Galore International Journal of Applied Sciences \& Humanities, vol. 3, no. 4, pp. 1-9, 2019.

[4] T. Guda, T. A. Mtaita, M. Mutetwa, T. Masaka, and P. P. Samkaange, "Plant growth promoting bacteria-fungi as growth promoter in wheat production," Journal of Asian Scientific Research, vol. 10, no. 3, pp. 141-155, 2020.

[5] K. Nyaera, T. A. Mtaita, M. Mutetwa, and T. Masaka, "Influence of maize seed inoculation with microbial bio fertilizers on morphological and physiological parameters of maize," International Journal of Science \& Healthcare Research, vol. 4, no. 4, pp. 31-37, 2019.

[6] D. Tavarwisa, C. Govera, M. Mutetwa, and W. Ngezimana, "Evaluating the suitability of baobab fruit shells as substrate for growing organic oyster mushroom (Pleurotus ostreatus)," International Journal of Agronomy, vol. 2021, Article ID 6620686, 7 pages, 2021.

[7] A. Tesfaw, A. Tadesse, and A. Tadesse, "Optimization of oyster (Pleurotus ostreatus) mushroom cultivation using locally available substrate and materials," Journal of Applied Biology and Biotechnology, vol. 3, no. 1, pp. 15-20, 2015.

[8] D. C. Zied, J. E. Pardo, R. S. Tomaz, C. T. Miasaki, and A. Pardo-Giménez, "Mycochemical characterization of
Agaricus subrufescens considering their morphological and physiological stage of maturity on the traceability process," BioMed Research International, vol. 2017, pp. 1-10, 2017.

[9] H. Yao, Y. Liu, Z. F. Ma et al., "Analysis of nutritional quality of black fungus cultivated with corn stalks," Journal of Food Quality, vol. 2019, Article ID 9590251, 5 pages, 2019.

[10] H. Stanley and N. Odu, "Cultivation of oyster mushroom (Pleurotus tuber-regium) on selected organic waste," International Journal of Advance Biological Research, vol. 2, pp. 446-448, 2012.

[11] P. C. K. Cheung, "Mini-review on edible mushrooms as source of dietary fiber: preparation and health benefits," Food Science and Human Wellness, vol. 2, no. 3-4, pp. 162-166, 2013.

[12] G. Deng, "A phase I/II trial of a polysaccharide extract from Grifola frondosa in breast cancer patients inmunological effects," Journal of Cancer Research and Clinical Oncology, vol. 135, no. 9, pp. 1215-1221, 2013.

[13] M. Lemieszek and W. Rzeski, "Anticancer properties of polysaccharides isolated from fungi of the Basidiomycetes class," Współczesna Onkologia, vol. 4, no. 4, pp. 285-289, 2012.

[14] X. Meng, H. Liang, and L. Luo, “Antitumor polysaccharides from mushrooms: a review on the structural characteristics, antitumor mechanisms and immunomodulating activities," Carbohydrate Research, vol. 424, pp. 30-41, 2016.

[15] C. Chaiyasut and B. S. Sivamaruthi, "Anti-hyperglycemic property of hericium erinaceus-a mini review," Asian Pacific Journal of Tropical Biomedicine, vol. 7, no. 11, pp. 1036-1040, 2017.

[16] N. Nowacka-Jechalke, R. Nowak, M. Juda et al., "New biological activity of the polysaccharide fraction from Cantharellus cibarius and its structural characterization," Food Chemistry, vol. 268, pp. 355-361, 2018.

[17] G. L. R. Dávila, A. W. Murillo, F. C. J. Zambrano, M. H. Suárez, and A. J. J. Méndez, "Evaluation of nutritional values of wild mushrooms and spent substrate of Lentinus crinitus (L.)," Fr. Heliyon.vol. 6, no. 3, Article ID e03502, 2020.

[18] N. K. Kortei, G. T. Odamtten, M. obodai, and M. W.-K. prempeh, "Survey of mushroom consumption and the possible use of gamma irradiation for sterilization of compost for its cultivation in southern Ghana," Agric \& Food Security, vol. 7, no. 83, 2018.

[19] U. R. Patar, R. Chandra, and P. K. Dhakad, "Coparative study on growth parameters and yield potential of two species of Pleurotus mushroom (Pleirotus florida and Pleirotus sajorcaju)," International Journl of Current Microbiology and Applied Sciences, vol. 7, no. 3066, pp. 2319-7706, 2018.

[20] S. Patel and A. Goyal, "Recent developments in mushrooms as anti-cancer therapeutics: a review," 3 Biotech, vol. 2, no. 1, pp. 1-15, 2012.

[21] Y. Zhang, W. Geng, Y. Shen, Y. Wang, and Y.-C. Dai, "Edible mushroom cultivation for food security and rural development in China: bio-innovation, technological dissemination and marketing," Sustainability, vol. 6, no. 5, pp. 2961-2973, 2014.

[22] B. C. Ijeoma, N. C. Ihediohanma, N. C. Onuegbu, and D. C. Okafor, "Nutritional composition and some anti-nutritional factors of three edible mushroom species in south eastern Nigeria," European Journal of Food Science and Technology, vol. 3, no. No.2, pp. 57-63, 2015.

[23] D. B. C. Ilechukwu and P. C. O. B. Okoye, "Cultivation of two species of mushroom found in anambra state, south-eastern, Nigeria and their potentials for bioremediation of trace metals 
polluted soil," International Journal of Trend in Scientific Research and Development, vol. 3, no. 3, pp. 1761-1772, 2019.

[24] A. Philippoussis, G. Zervakis, and P. Diamantopoulou, "Bioconversion of agricultural lignocellulosic wastes through the cultivation of the edible mushrooms Agrocybe aegerita, Volvariella volvacea and Pleurotus spp. World," World Journal of Microbiology and Biotechnology, vol. 17, no. 2, pp. 191-200, 2001.

[25] G. Olivieri, A. Marzocchella, P. Salatino, P. Giardina, G. Cennamo, and G. Sannia, "Olive mill wastewater remediation by means of Pleurotus ostreatus," Biochemical Engineering Journal, vol. 31, no. 3, pp. 180-187, 2006.

[26] S. Li and N. P. Shah, "Characterization, antioxidative and bifidogenic effects of polysaccharides from Pleurotus eryngii after heat treatments," Food Chemistry, vol. 197, pp. 240-249, 2016.

[27] M. B. Bellettini, F. A. Fiorda, H. A. Maieves et al., "Factors affecting mushroom Pleurotus spp," Saudi Journal of Biological Sciences, vol. 26, no. 4, pp. 633-646, 2019.

[28] A. F. Eira and A. Fácil Viçosa, Cultivo Do Cogumelo Medicinal, (in Portuguese), 2003.

[29] AMGA, The Australian Mushroom Growers Association (AMGA), Locked Bag 3, 2, Forbes St., Windsor, Australia, 2004.

[30] Y. Besufekad, A. Mekonnen, B. Girma et al., "Selection of appropriate substrate for production of oyster mushroom (Pleurotus ostreatus)," Journal of Yeast and Fungal Research, vol. 11, no. 1, pp. 15-25, 2020.

[31] M. Mutema, K. Basira, D. Savadye, and W. Paravira, "Assessment of oyster mushroom production and profitability in harare urban and periurban areas (RUWA), Zimbabwe," Tanzania Journal of Science, vol. 45, no. 1, pp. 114-130, 2019.

[32] W. Ngezimana, T. A. Mtaita and I. Mtukwa, Potential of organic residues in producing oyster mushroom, Pleurotus ostreatus Fr," International Journal of Biological and Chemical Sciences, vol. 1, no. 2, pp. 108-120, 2007.

[33] E. A. Adebayo and D. Martínez-Carrera, "Oyster mushrooms (Pleurotus) are useful for utilizing lignocellulosic biomass," African Journal of Biotechnology, vol. 14, no. 1, pp. 52-67, 2015.

[34] F. B. Muchena, C. Pisa, M. Mutetwa, C. Govera, and W. Ngezimana, "Effect of spent button mushroom substrate on yield and quality of baby spinach (Spinacia oleracea)," International Journal of Agronomy, vol. 2021, Article ID 6671647, 9 pages, 2021.

[35] E. P. Contreras, M. Sokolov, G. Mejía, and J. E. Sánchez, "Soaking of substrate in alkaline water as a pretreatment for the cultivation of Pleurotus ostreatus," The Journal of Horticultural Science and Biotechnology, vol. 79, no. 2, pp. 234-240, 2004.

[36] D. K. Bhattacharjya, R. K. Paul, R. K. Paul, M. N. Miah, and K. U. Ahmed, "Effect of different saw dust substrates on the growth and yield of oyster mushroom (Pleurotus ostreatus)," IOSR Journal of Agriculture and Veterinary Science, vol. 7, no. 2, pp. 38-46, 2014.

[37] E. G. Silva, E. S. Dias, F. G. Siqueira, and R. F. Schwan, "Análise química de corpos de frutificação de Pleurotus sajorcaju cultivado em diferentes concentrações de nitrogênio," Ciência e Tecnologia dos Alimentos, vol. 27, no. 1, pp. 72-75, 2007.

[38] F. Patrick, G. Y. S. Mtui, A. M. Mshandete, and A. K. Kivaisi, "Ligninolytic enzymes activities of Pleurotus sapidus P969 during vegetative growth and fruit development on sugarcane residues-based substrates," International Journal of Biotechnology, vol. 4, no. 3, pp. 58-71, 2014.

[39] R. Naraian, R. K. Sahu, S. Kumar, S. K. Garg, C. S. Singh, and R. S. Kanaujia, "Influence of different nitrogen rich supplements during cultivation of Pleurotus florida on corn cob substrate," The Environmentalist, vol. 29, no. 1, pp. 1-7, 2008.

[40] S. S. Mkhize, J. Cloete, A. K. Basson, and G. E. Zharare, "Performance of Pleurotus ostreatus mushroom grown on maize stalk residues supplemented with various levels of maize flour and wheat bran," Food Science And Technology, vol. 36, no. 4, pp. 598-605, 2016.

[41] W. Yang, F. Guo, and Z. Wan, "Yield and size of oyster mushroom grown on rice/wheat straw basal substrate supplemented with cotton seed hull," Saudi Journal of Biological Sciences, vol. 20, no. 4, pp. 333-338, 2013.

[42] S. Alborés, M. J. Pianzzola, M. Soubes, and M. P. Cerdeiras, "Biodegradation of agroindustrial wastes by Pleurotus spp for its use as ruminant feed," Electronic Journal of Biotechnology, vol. 9, pp. 215-220, 2006.

[43] N. .,F. Chukwurah, S. C. Eze, N. V. Chiejina et al., "Correlation of stipe length, pileus width and stipe girth of oyster mushroom (Pleurotus ostreatus) grown in different farm substrates," Journal of Agricultural Biotechnology and Sustainable Development, vol. 5, no. 3, pp. 54-60, 2013.

[44] Z. Tsegaye and G. Tefera, "Cultivation of oyster mushroom (Pleurotus ostreatus kumm, 1871) using agro-industrial residues," Journal of Applied Microbiological Research, vol. 1, no. 1, pp. 1-6, 2017.

[45] E. U. Onyeka, E. Udeogu, C. Umelo, and M. A. Okehie, "Effect of substrate media on growth, yield and nutritional composition of domestically grown oyster mushroom (Pleurotus ostreatus)," African Journal of Plant Science, vol. 12, no. 7, pp. 141-147, Article ID 995A48757899, 2018.

[46] D. Dubey, B. Dhakal, K. Dhami et al., "Comparative study on effect of different substrates on yield performance of oyster mushroom," Global Journal of Biology, Agriculture \& Health Sciences, vol. 7, p. 7, 2019.

[47] P. Sanjel, R. K. Shrestha, and J. Shrestha, "Performance of oyster mushroom (Pleurotus ostreatus) grown on different fingermillet husk substrates," Journal of Agriculture And Natural Resources, vol. 4, no. 1, pp. 291-300, 2021.

[48] A. L. Zanetti and M. A. Ranal, "Efeito de diferentes resíduos agroindustriais na miceliação de Pleurotus sp. "florida," em uberlândia, MG,” Pesquisa Agropecuária Brasileira, vol. 31, no. 3, pp. 215-220, 1996.

[49] D. Hernández, J. E. Sánchez, and K. Yamasaki, “A simple procedure for preparing substrate for Pleurotus ostreatus cultivation," Bioresource Technology, vol. 90, no. 2, pp. 145-150, 2003.

[50] E. M. Moda, J. Horii, and M. H. F. Spoto, "Edible mushroom Pleurotus sajor-caju production on washed and supplemented sugarcane bagasse," Scientia Agricola, vol. 62, no. 2, pp. 127-132, 2005

[51] F. G. d. Siqueira, E. T. Martos, R. d. Silva, and E. S. Dias, "Cultivation of Pleurotus sajor-caju on banana stalk and bahia grass based substrates," Horticultura Brasileira, vol. 29, no. 2, pp. 199-204, 2011.

[52] C. Zied, J. M. Savoie, and P.-G. Arturo, "Soybean the main nitrogen source in cultivation substrates of edible and medicinal mushrooms," in Soybean and Nutrition, H. El-Shemy, Ed., , 2011.

[53] M. K. Basak, S. Chanda, S. K. Bhaduri, S. B. MondaL, and R. Nandi, "Recycling of jute waste for edible mushroom 
production," Industrial Crops and Products, vol. 5, no. 3, pp. 173-176, 1996.

[54] Z. Girmay, W. Gorems, G. Birhanu, and S. Zewdie, "Growth and yield performance of Pleurotus ostreatus (Jacq. Fr.) kumm (oyster mushroom) on different substrates," AMB Express, vol. 6, no. 1, pp. 1-7, 2016.

[55] W. Islam and A. Riaz, "Yield and biological efficiency of Pleurotus ostreatus (JACQ. FR.) cultivated upon various weeds and agricultural wastes," Pakistan Journal of Weed Science Research, vol. 23, pp. 271-279, 2017.

[56] D. Wang, A. Sakoda, and M. Suzuki, "Biological efficiency and nutritional value of Pleurotus ostreatus cultivated on spent beer grain," Bioresource Technology, vol. 78, no. 3, pp. 293-300, 2001.

[57] H. T. Hoa, C.-L. Wang, and C.-H. Wang, "The effects of different substrates on the growth, yield, and nutritional composition of two oyster mushrooms (Pleurotus ostreatus and Pleurotus cystidiosus)," Mycobiology, vol. 43, no. 4, pp. 423-434, 2015.

[58] N. R. Curvetto, D. Figlas, R. Devalis, and S. Delmastro, "Growth and productivity of different Pleurotus ostreatus strains on sunflower seed hulls supplemented with $\mathrm{N}-\mathrm{NH}_{4}{ }^{+}$ and/or Mn (II)," Bioresource Technology, vol. 84, no. 2, pp. 171-176, 2002.

[59] M. Bonatti, P. Karnopp, H. M. Soares, and S. A. Furlan, "Evaluation of Pleurotus ostreatus and Pleurotus sajor-caju nutritional characteristics when cultivated in different lignocellulosic wastes," Food Chemistry, vol. 88, no. 3, pp. 425-428, 2004.

[60] B. Gume, D. Muleta, and A. Dawit, "Evaluation of locally available substrates for cultivation of oyster mushroom (Pleurotus ostreatus) in Jimma, Ethiopia," African Journal of Microbiology, vol. 7, pp. 2228-2237, 2013. 